\title{
Appraising the Module Deployment Operation in the RLWI Units
}

Arvind Keprate and Mohammed Ali Mohammed

University of Stavanger, Stavanger 4036, Norway

\begin{abstract}
RLWI (Riserless Light Well Intervention) technology has the advantage of utilizing a special subsea lubricator to perform intervention activities in water depths of up to 1,200 $\mathrm{m}$ without the need for the marine risers. Utilizing the technology, oil companies have been able to save up to $50 \%$ on the intervention costs. However, in the last five years, it has seen up to $25 \%$ downtime due to waiting on weather (wow). Thus, in this manuscript, it is attempted to identify the critical elements of the module deployment system and analyze their significance in the objective of raising the operational weather limit. Critical failure modes were found to be failure of crane wire due to excess loading, failure of the lower cursor system due to the impact loading and clashing of the module with the moonpool walls. Analysis of the module deployment system against these failure modes was ensued by using Orcaflex. The results showed the moonpool sea state to be the defining parameter. Although, changing moonpool dimensions affect hydrodynamics positively, however it's significance is small due to dependency on the vessel's breadth. Based on these results and the available data for the analysis, a recommended system particular was tested. Significance improvement, in lowering the risk of failure was observed.
\end{abstract}

Key words: Module handling system, RLWI, FMEA, time domain analysis.

\section{Introduction}

SPS (Subsea production systems) are still in the development age and one of the biggest drawbacks is their high cost of administering well interventions. This is mainly because, unlike platform wells that can be accessed directly from the host platforms; the subsea wells can only be accessed by connecting floating intervention rigs to the subsea trees through expensive intervention equipment [1]. Due to this, well interventions on subsea wells are performed less frequently resulting in an estimated $20 \%$ reduction in their hydrocarbon recovery rates [2]. Hence, reducing the cost of well interventions has been a key area of concern for the subsea industry.

The introduction of the RLWI (Riserless Light Well Intervention) technology in the oil and gas market has been partly successful at lowering some of the cost of subsea well interventions. The technology involves using a new riser-less subsea intervention equipment,

Corresponding author: Arvind Keprate, research fellow, research field: offshore operations. as compared to the traditional riser-based one. The absence of the heavy risers on-board makes it possible to perform RLWI subsea well interventions on smaller, faster, and cheaper mono-hull vessels and hence, significantly reduces cost per operation. However, RLWI is currently highly inefficient. Based on the current RLWI vessels statistics, the vessels are at an average of $25 \%$ down time over the last 4 years [3]. This is unsatisfactory because it has resulted in fewer interventions per year, delay of potential oilercovery and subsequently affecting the project developers' yearly revenue.

The grounds for downtime is mainly associated with weather criteria on-board the RLWI units. Transiting to key side and waiting on weather (wow) accounts to more than three quarters of the total downtime. The main reason for low operability weather limit of the vessels is found to be low design weather criteria for the module deployment operation on the NCS (Norwegian Continental Shelf). Therefore, raising the operability criteria of the module deployment system for the future RLWI units plays a key role in improving 
the efficiency.

In light of the above discussion, the main aim of this manuscript is to evaluate the module deployment operation in the RLWI units. The results of the FMEA (Failure Modes and Effect Analyses) are used to identify the critical failure modes in the aforementioned process. The remainder of the manuscript is organized as follows. Section 2 of the paper gives a brief introduction about the RLWI and the RLWI stack. Thereafter, in Section 3 a case study evaluating the module deployment operation in the RLWI units is performed using Orcaflex. Afterwards, the results and discussion on the results have been made. Finally, a suitable conclusion is presented in Section 4.

\section{RLWI}

\subsection{Definition\& RLWI Stack}

Well intervention is "a collective term used for activities that are performed on a live production or injection well, to alter its state, for a required period of time”. In particular, when a well intervention is done with the special subsea lubricator in place of a marine riser, the well intervention is then termed as RLWI.

The RLWI is performed from a special RLWI vessels (also called Category A vessel) in order to minimize the cost of wire-line interventions. It achieves this by using a riser-less intervention technology with a patented subsea lubricator, called the RLWI stack. The RLWI stack utilizes pressurized grease seal technology that allows it to seal off hydrocarbons near the sea bottom, removing the need for the risers. Therefore, wire-line interventions could possibly be carried out on smaller vessels which have lower day rates and faster transit speeds. From experience, $40-50 \%$ reduction in cost per intervention compared with conventional rigs has been attained [3].

The lynchpin of the RLWI technology is a RLWI stack shown in Fig. 1 [4].

Basically, the RLWI stack gets its name from its comprising parts being stacked on top of one another. It has five main components as shown in Fig 1. The basic components are shown in Ref. [4]:

(1). PCH (Pressure Control Head): The top most section of the RLWI stack is the pressure control head. It consists of a locking tool with the upper lubricator

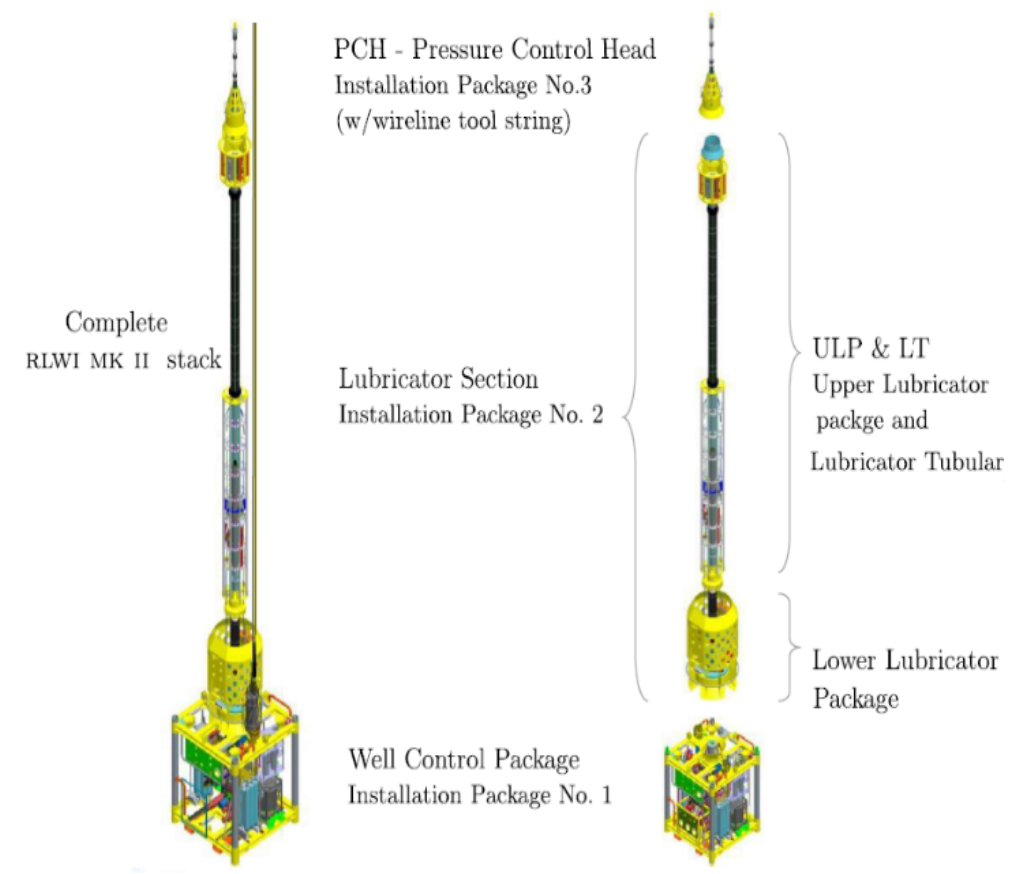

Fig. 1 RLWI Mark II assembly [4]. 
package as well as the flow tubes responsible for providing the grease seal function. The $\mathrm{PCH}$ also serves as a primary well barrier;

(2). ULP (Upper Lubricator Package): It is located beneath the $\mathrm{PCH}$, and contains the ball valve for cutting the wireline string in case of the emergency. In addition, it has the grease circulation outlet and a connection hub for the $\mathrm{PCH}$;

(3). LT (Lubricator Tubular): The LT is located between the lower and upper lubricator packages. It is not only a host for grease reservoirs but also to the injection pumps. The LT, together with upper and lower lubricator packages also act as a storage or parking facility for the intervention tools. This is necessary to pressurize the tool higher than the well head pressure before entering the live well;

(4). LLP (Lower Lubricator Package): The LLP houses several components that allow the control of the RLWI stack. These include: the subsea control module, the hydraulic power unit, hydraulic reservoirs, accumulators, and process control domain etc. Nevertheless, more importantly, the LLP is connected to the well control package through a safety joint. The safety joint is a critical element allowing the lubricator section to bend and not transfer the bending moment to the well control package;

(5). WCP (Well Control Package): It is the main mechanical safety barrier of the RLWI stack. It is connected, hydraulically to the $\mathrm{x}$-mass tree through an adapter suiting the type of $\mathrm{x}$-mass tree. It contains a series of upper valves and lower valves, as well as the shear/seal ram. In emergencies, it is able to cut through wireline, wireline tool string, coiled tubing, as well as drill pipe and pressure shut in. During interventions, it provides communication panels from work-over control system to the $\mathrm{x}$-mass tree.

The RLWI technology has been qualified for its reliability and safety. The equipment is verified by relevant standards, such as Norsok D-002 [5] and DNV-OS-E101 [6] among others, to perform operations in the North Sea and Norwegian Sea for up to a depth of $500 \mathrm{~m}$.

\subsection{RLWI Challenges}

Although the technology is quick and cost effective, RLWI is currently highly inefficient. Based on the current RLWI vessels statistics, the vessels are at an average of $25 \%$ down time over the last 4 years [3]. This is unsatisfactory because it results in fewer interventions per year, delay of potential oil recovery and subsequently damaging the company's yearly revenue.

The grounds for downtime are mainly associated with operational weather criteria on board. Transiting to key side and wow for these operations takes more than three quarters of the total downtime. The main reasons for wow are:

(1). Operational weather limits on the vessels are too low compared to apparent sea states on site;

(2). Low confidence on the operational weather limit;

(3). Low confidence on on-site weather measurement method.

Table 1 shows the operability criteria $\left(O P_{W F}\right)$ for oneofthe vessels used in the North Sea. It can be seen that module deployment is a critical operation based on

Table $1 O P_{W F}$ criteria for one of the vessels in the North Sea.

\begin{tabular}{llllll}
\hline Design modes & \multicolumn{5}{c}{ Maximum displacement (single amplitudes) } \\
\cline { 2 - 6 } & Heave $(\mathrm{m})$ & Roll $(\mathrm{m})$ & Pitch $(\mathrm{m})$ & Surge $(\mathrm{m})$ & Sway $(\mathrm{m})$ \\
\hline $\begin{array}{l}\text { Well intervention operations } \\
H_{s}=6 m / T_{p}=12.4 s\end{array}$ & 4.2 & 4.6 & 7.9 & 3.4 & 1.8 \\
$\begin{array}{l}\text { Module deployment } \\
H_{s}=4 m / T_{p}=10.1 \mathrm{~s}\end{array}$ & 2.1 & 2.9 & 5.7 & 1.6 & 0.9 \\
$\begin{array}{l}\text { Horizontal skidding of the module } \\
H_{s}=4 m / T_{p}=10.1 \mathrm{~s}\end{array}$ & 2.1 & 2.9 & 5.7 & 1.6 & 0.9 \\
\hline
\end{tabular}


the operability criteria. Therefore, raising the operability criteria of the module deployment system for the future RLWI units plays a key role in improving the efficiency. Thus, a case study evaluating the module deployment operation in the RLWI units is performed in Section 3 using the Orcaflex software.

\section{Illustrative Case Study}

\subsection{Purpose and Scope}

The purpose of the analysis is to evaluate the module deployment operation in the RLWI units. In this manuscript, the analysis is performed for the three main load cases depicted in Fig. 2. For each load case, the module is hanged at a specified location and the simulations are run for each load combinations. The three load cases and load combinations used in this case study are outlined below:

(1). Load Cases:

- Case A: Module top $1 \mathrm{~m}$ above still water surface (inside moonpool, regular wave analysis);

- Case B: Module top $1 \mathrm{~m}$ below still water surface (inside moonpool, regular wave analysis) and

- Case C: Module top in-line with vessel keel (below moonpool, irregular wave analysis).
(2). Load Combinations:

- 2 wave heading (180 degree and 150 degree);

- 5 wave periods (6-10 s);

- 5 seeds (for irregular wave analysis only);

- Selected significant wave heights (1-4 m).

The base case is used as a benchmark to get an idea of the operation and the expected loads involved. The base case particulars are outlined below:

- Vessel Length = $137 \mathrm{~m}$;

- Vessel gross weight $=21.46 \mathrm{t}$;

- Draught = $7.74 \mathrm{~m}$;

- Moonpool size $=7.8 \times 7.8 \mathrm{~m}^{2}$;

- Moonpool damping ratio $=30 \%$;

- Guide wire tension $=35 \mathrm{kN}$;

- Heave Compensation = 0\%;

- Tower height = 25 m from deck level;

- Load case A and B: Regular wave analysis (Airy wave theory, no current);

- Load case C: Irregular wave analysis (Torsethaugen wave spectra, 1-year current).

\subsection{Location}

The location of the operation is selected to be in the Norwegian Sea. We have considered Åsgard field in

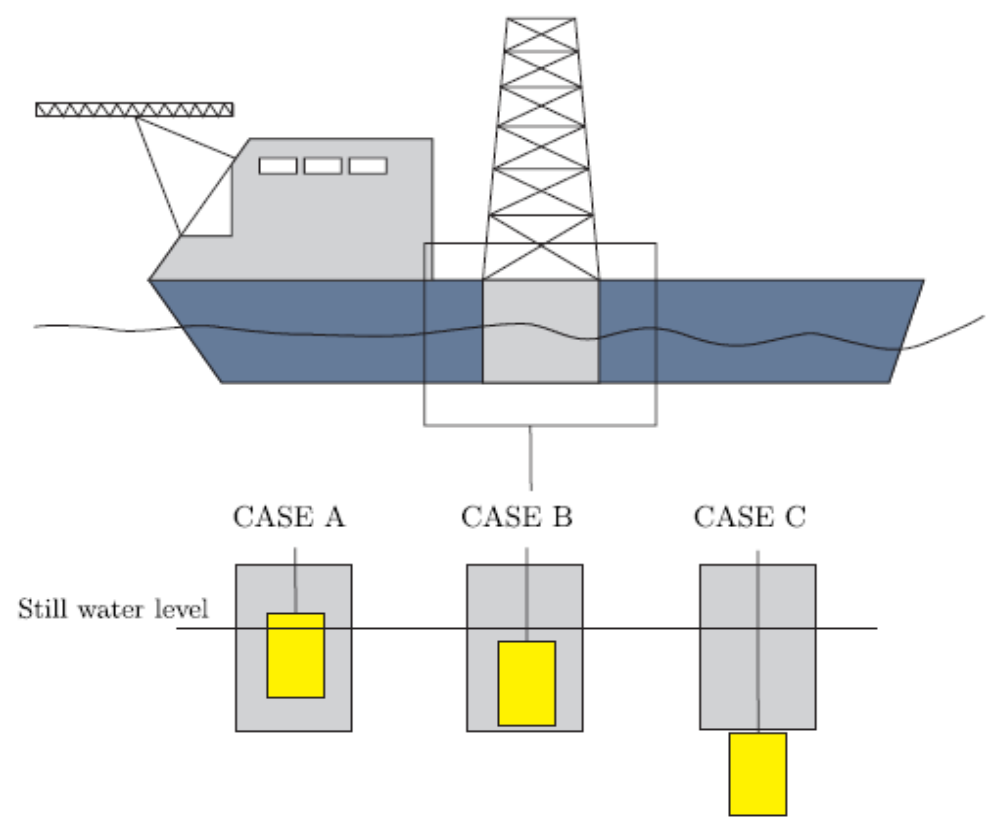

Fig. 2 Load case definition used in analysis. 
our case study as it has significant number of subsea wells (total 57) and the wells have been in the operation for over ten years; thus, they would probably need more frequent intervention works. Moreover, the Åsgard field has depth ranging from 280 to $380 \mathrm{~m}$. Such a depth is considered as a deep water condition for wave periods smaller than $18.9 \mathrm{~s}$ (as $\frac{d}{L}>0.5$ ). In our case study, we have assumed a design water depth of $350 \mathrm{~m}$ in the Åsgard field, and carried out our analysis for the aforementioned water depth.

\subsection{Failure Modes}

The RLWI deployment operation can fail in many ways. A FMEA was conducted to analyze the possible failure modes. The results of FMEA are depicted in the Table A1 shown in the Appendix. A summary of the critical failure modes shown in Fig. 3 are:

(1). Load Case A and B:

- Main crane wire failure due to excessive loading/snapping beyond capacity;

- Lower cursor system failure due to high impact loading from module.

(2). Load Case C:

- Main crane wire failure due to excessive loading/snapping beyond capacity;

- Module component failure because of clashing to the moonpool bottom edges during deployment and/or retrieval.

\subsection{Analysis Model}

The time domain analysis performed in this manuscript is performed on Orcaflex 9.7 software package. The model for our case study comprises of the installation vessel (IV), a module (i.e. MKII stack), four lifting slings and a crane winch wire. The Orcaflex model of IV and associated information about loading condition and displacement RAOs are taken from one of the engineering contractors. Since, the weight of the module is less than $1 \%$ of the total mass of the vessel, therefore, it is assumed that module has very less influence on the vessels motion [7].

The module is a complex structure consisting of many parts with varying hydrodynamic properties. The Orcaflex 3-D model MKII stack used in the analysis is depicted in Fig. 5.

In order to capture the load incurred by the module at any given time and location, as accurately as possible, we need to have the information regarding the following:

(1). Geometry of the module;

(2). Structural mass and mass moment of inertia;

(3). Volume;

(4). Hydrodynamic Coefficients.

The information regarding the first three parameters is gained from past operational experience and is tabulated in Table 2.

The raw added mass coefficients for the fully submerged module far from the surface of water, before the effect of moonpool walls, perforation, shielding, interaction or trapped water are accounted, and are shown in Table 3. Furthermore, the drag coefficients were calculated based on the suggestions of O. Øritsland's drag coefficient plot [8]. The results

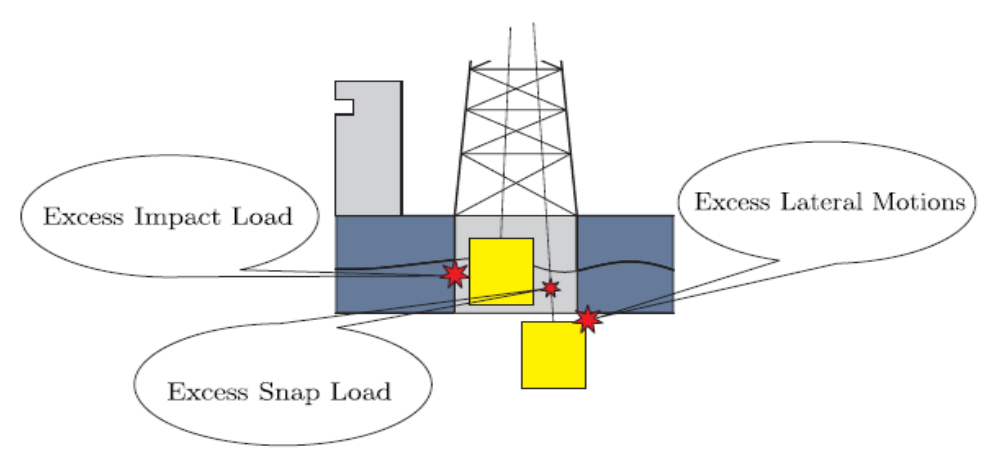

Fig. 3 Critical structural failure modes considered for analysis. 


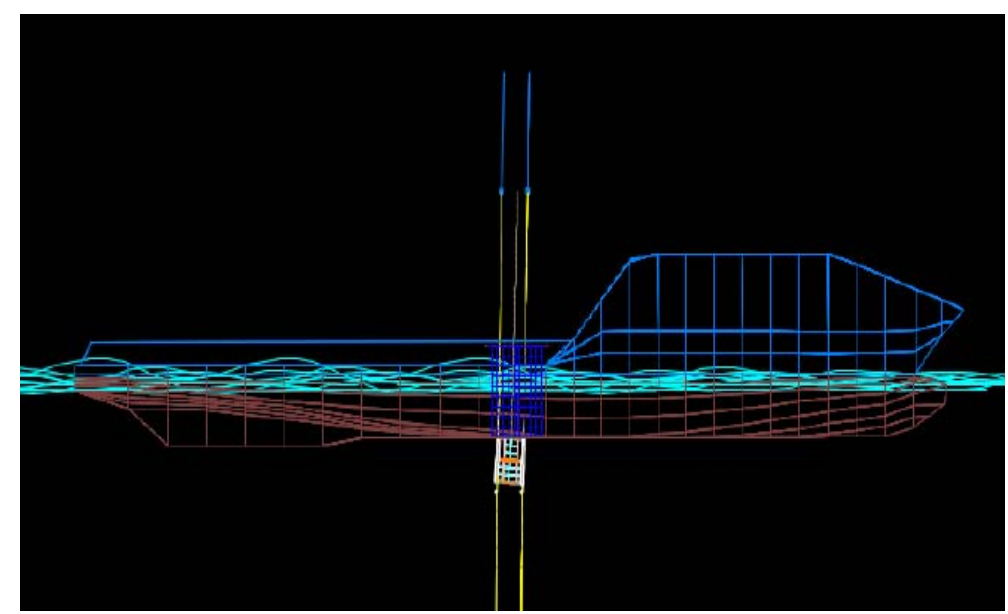

Fig. 4 Wireframe Orcaflex model.

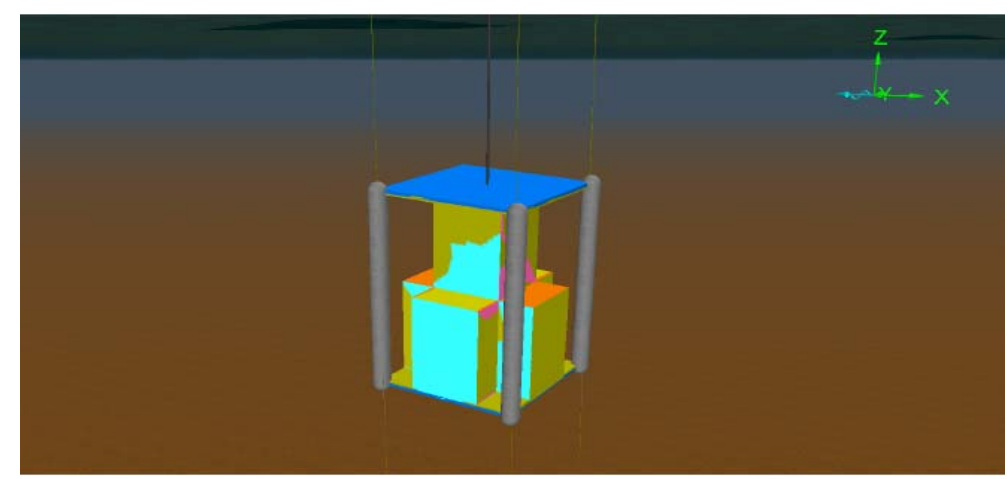

Fig. 5 3D MKII stack model.

Table 2 General MKII module data.

\begin{tabular}{lll}
\hline Parameter & Unit & Value \\
\hline Weight & $\mathrm{t}$ & 50 \\
Width & $\mathrm{m}$ & 4 \\
Length & $\mathrm{m}$ & 4 \\
Height & $\mathrm{m}$ & 6 \\
Fully submerged volume & $\mathrm{cu} . \mathrm{m}$ & 38 \\
Perforation & $\%$ & 65 \\
\hline
\end{tabular}

are depicted in Table 4.

\subsection{Results and Discussion}

\subsubsection{Result}

According to the FMEA analysis, the critical areas of failure or critical failure modes for our case study are: crane wire loading, impact velocity when module is inside the moonpool, and the lateral motions of the module at the keel level. The results (in terms of aforementioned parameters) for the three load cases (i.e. load case A, B, and C are presented in Fig. 7, Fig. 8 and Fig. 9 respectively. The base case is used as a bench mark in order to get an idea of the operation and the expected loads involved. For the base case, following observations are made:

(1). Loads due to the 180 degree wave headings were observed to have larger impact than 150 degree wave headings;

(2). Crane wire loads are observed to be larger on the load case $\mathrm{A}$ and are reduced as the module goes down the moonpool; as witnessed in the load case B and C;

(3). Maximum crane wire loads could reach up to $350 \mathrm{t}$, implying the minimum breaking limit of the wire to be $4.25 \times 350=1,486 \mathrm{t}$, well above the crane wire specification limit of $367 \mathrm{t}$;

(4). Minimum crane wire loads are near zero on load cases $\mathrm{A}$ and $\mathrm{B}$, indicating the presence of the snap loading;

(5). Relative to the moonpool/vessel, the module could have maximum heave motions up to $2 \mathrm{~m}$ at $6 \mathrm{~s}$ wave periods; 
Table 3 Global added mass coefficients for module parts.

\begin{tabular}{llllllll}
\hline Object & Funnels & Roof & Floor & Block type 1 & Block type 2 & Block type 3 & Block type 4 \\
\hline Shape & $\begin{array}{l}\text { Hollow } \\
\text { cylinder }\end{array}$ & $\begin{array}{l}\text { Rectangular } \\
\text { plate }\end{array}$ & $\begin{array}{l}\text { Rectangular } \\
\text { plate }\end{array}$ & $\begin{array}{l}\text { Rectangular } \\
\text { block }\end{array}$ & $\begin{array}{l}\text { Rectangular } \\
\text { block }\end{array}$ & $\begin{array}{l}\text { Rectangular } \\
\text { block }\end{array}$ & $\begin{array}{l}\text { Rectangular } \\
\text { block }\end{array}$ \\
\hline Width/Dia. & 0.25 & 4.0 & 4.0 & 1.0 & 2.0 & 2.0 & 2.0 \\
Length/Thick. & 0.01 & 4.0 & 4.0 & 2.0 & 2.0 & 2.0 & 3.0 \\
Height & 6.0 & 0.1 & 0.1 & 3.0 & 6.0 & 3.0 & 4.0 \\
\hline Added mass coefficients & & & & & & & 0.92 \\
\hline $\boldsymbol{C}_{\boldsymbol{x}}$ & 0.96 & 0.00 & 0.00 & 0.99 & 1.29 & 1.07 & 1.20 \\
$\boldsymbol{C}_{\boldsymbol{y}}$ & 0.96 & 0.00 & 0.00 & 1.36 & 1.29 & 1.07 & 1.13 \\
$\boldsymbol{C}_{\boldsymbol{z}}$ & 0.96 & 0.58 & 0.58 & 1.28 & 0.98 & 0.91 & \\
\hline Reference volumes & & & & & & \\
\hline $\boldsymbol{V}_{\boldsymbol{R} \boldsymbol{x}}, \boldsymbol{m}^{\mathbf{3}}$ & 0.29 & 50.27 & 50.27 & 9.42 & 18.85 & 9.42 & 28.27 \\
$\boldsymbol{V}_{\boldsymbol{R} \boldsymbol{y}}, \boldsymbol{m}^{\mathbf{3}}$ & 0.29 & 50.27 & 50.27 & 2.36 & 18.85 & 9.42 & 12.57 \\
$\boldsymbol{V}_{\boldsymbol{R} \boldsymbol{z}}, \boldsymbol{m}^{\mathbf{3}}$ & 0.29 & 50.27 & 50.27 & 1.57 & 6.28 & 6.28 & 9.42 \\
\hline
\end{tabular}

Table 4 Drag coefficients used for the analysis.

\begin{tabular}{lllll}
\hline \multirow{2}{*}{ Load case } & \multicolumn{5}{c}{ Moonpool size $(\mathrm{m})$} \\
\cline { 2 - 5 } & 7.6 & 7.8 & 8 & 8.2 \\
\hline Case A & 6.12 & 5.96 & 5.82 & 5.69 \\
Case B & 6.67 & 6.5 & 6.34 & 6.21 \\
Case C & 3.93 & 3.93 & 3.93 & 3.93 \\
\hline
\end{tabular}

(6). Impact surge velocity could reach up to $1.6 \mathrm{~m} / \mathrm{s}$, while sway impact velocity could reach up to $2 \mathrm{~m} / \mathrm{s}$;

(7). Maximum acceleration of the module in the moonpool could reach up to $5 \mathrm{~m} / \boldsymbol{s}^{2}$ while sway acceleration could be double that amount;

(8). At keel level (i.e. load case $\mathrm{C}$ ), the module has the maximum lateral motion of $2.2 \mathrm{~m}$ exceeding the moonpool boundaries limit of $1.9 \mathrm{~m}$, indicating the possibility of clashing to the moonpool walls.

\subsubsection{Discussion}

The first point under Section 3.5.1 indicates that the crane wire forces are larger for the 180 degree wave headings. To understand this result, one needs to know the factors affecting the crane wire loads. Generally, there are two main factors affecting the crane wire end loads, these are: the crane tip motions and the hydrodynamic loads on the structure. For the base case, the crane tip motions mainly depend on the heave motion transfer functions. These are shown to be lower for waves heading in the 180 degree direction compared to the waves in the 150 degree direction, as depicted in Fig. 10. The effect of having lower transfer function for a module within splash zone, is that, it increases the relative velocity of the sea water to the module. Hence, increasing the upward hydrodynamic load that is applied in the module. In addition, when the wave heading is at 180 degree, the moonpool sea state RAO is slightly "worse off”, as shown in Fig. 11. This again, will result in the higher hydrodynamic loading, resulting in the larger crane wire forces for the 180 degree wave headings.

The second point indicates that the load case A, shows a higher loading condition than the other cases. This is in line with the basic hydrodynamic theories which state that wave loads are highest at the splash zone crossing and decrease as we go down the depth.

Points three and four show, the high values of the crane wire loads and the indication of snapping. Snapping occurs when the upward hydrodynamic loads on the module are greater than its static weight. This was evident in simulation results in load cases A and B. It should be noted that when using the regular wave analysis, the wave height used is the maximum wave height valued at 2 times the value of the significant 


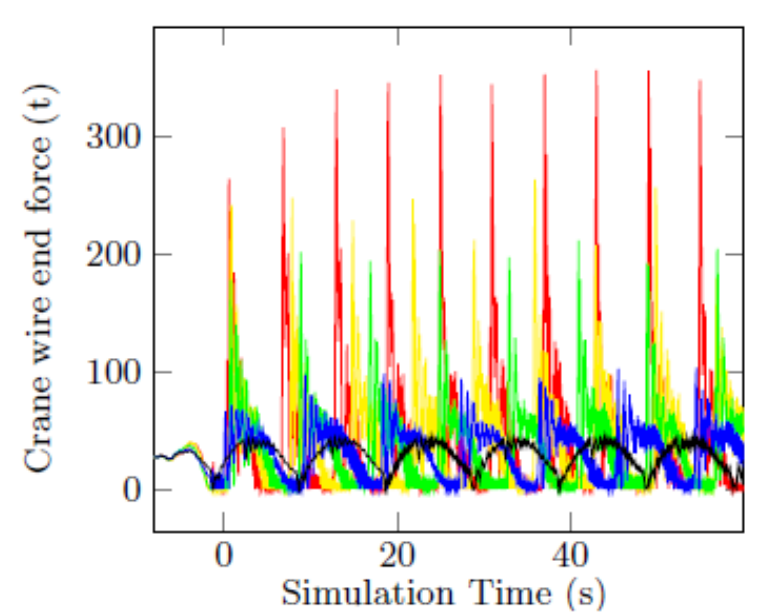

(a) Crane wire end force

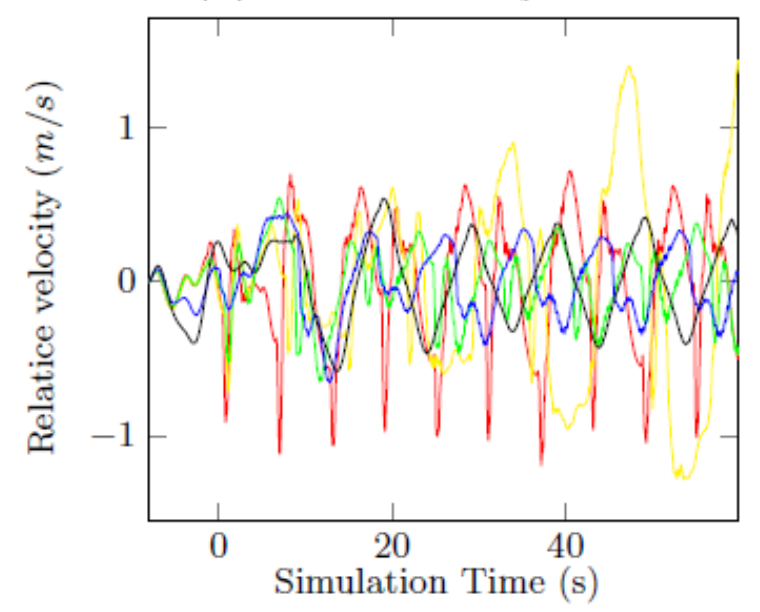

(c) Surge relative velocity

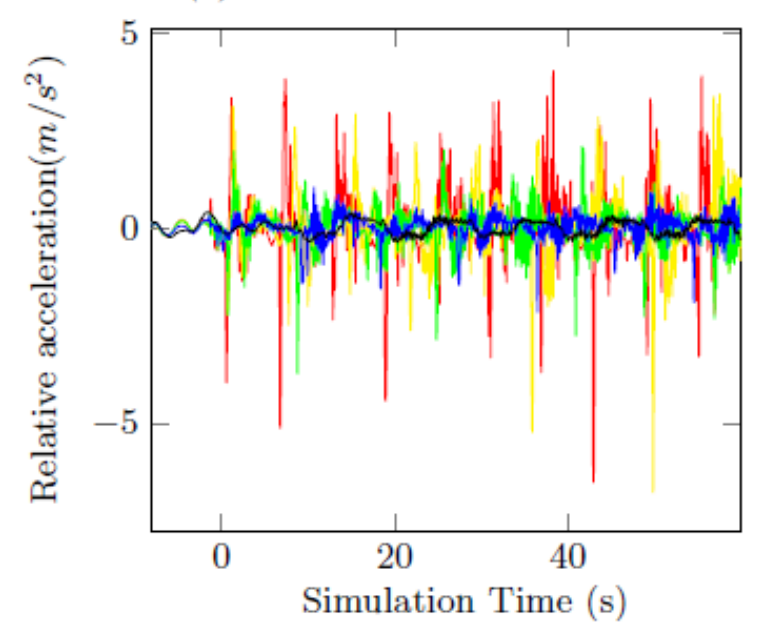

(e) Surge relative acceleration

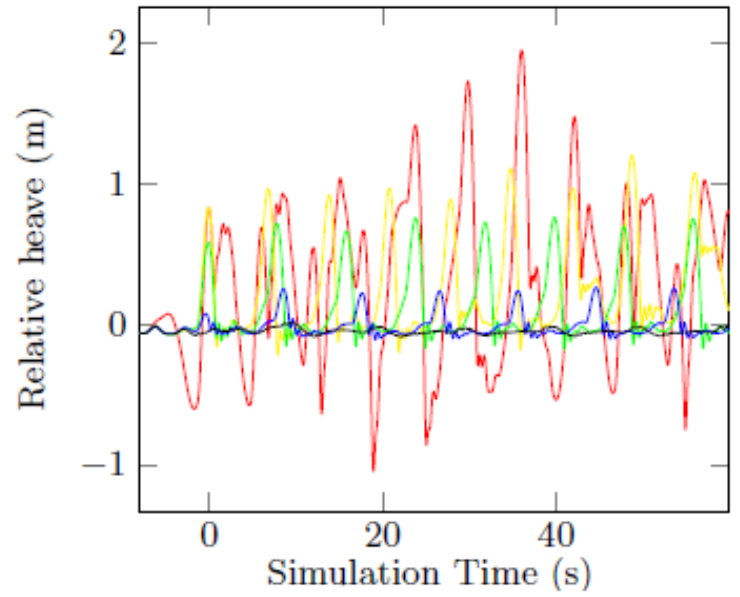

(b) Heave motion

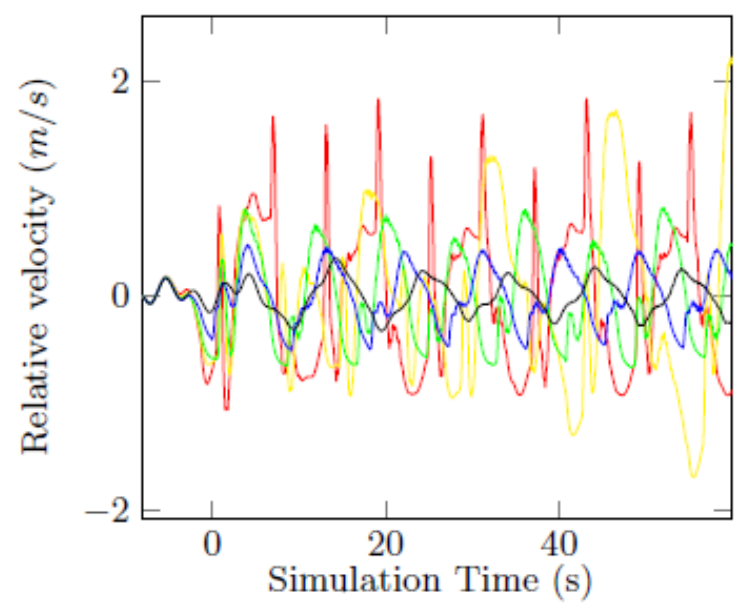

(d) Sway relative velocity

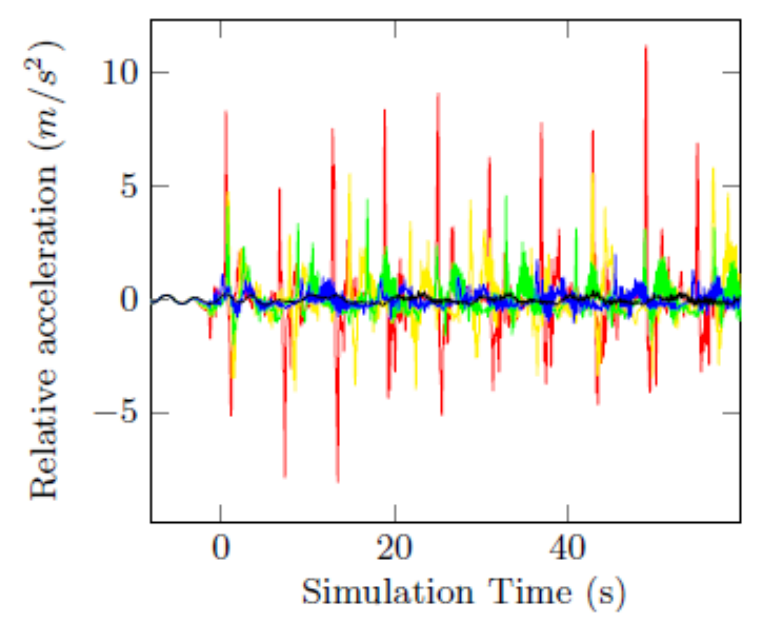

(f) Sway relative acceleration

$$
-T p=6 s-T p=7 s-T p=8 s-T p=9 s-T p=10 s
$$

Fig. 7 Base Case A: Results relative to moonpool at $H_{s}=2.5 \mathrm{~m}$ and 180 degree wave direction. 


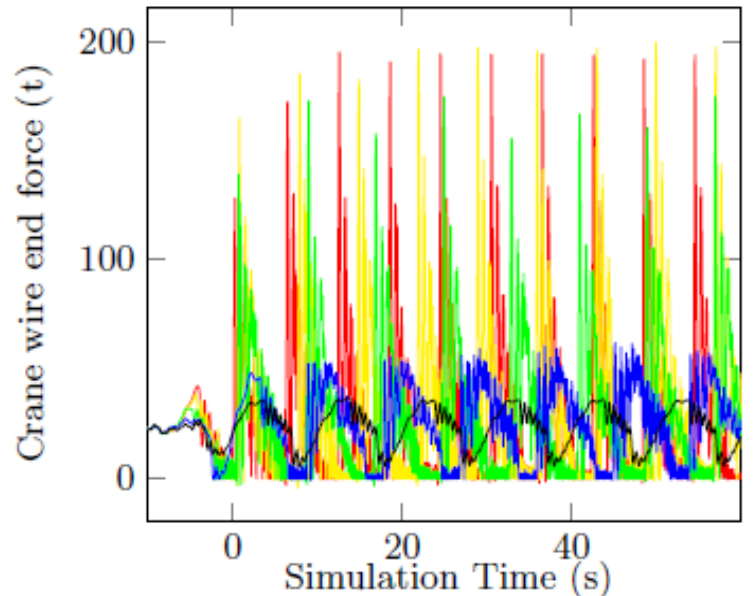

(a) Crane wire end force

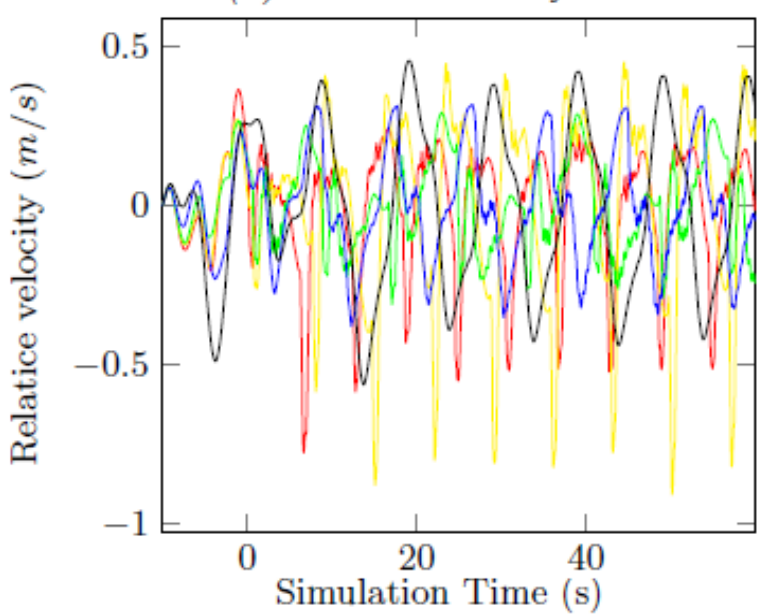

(c) Surge relative velocity

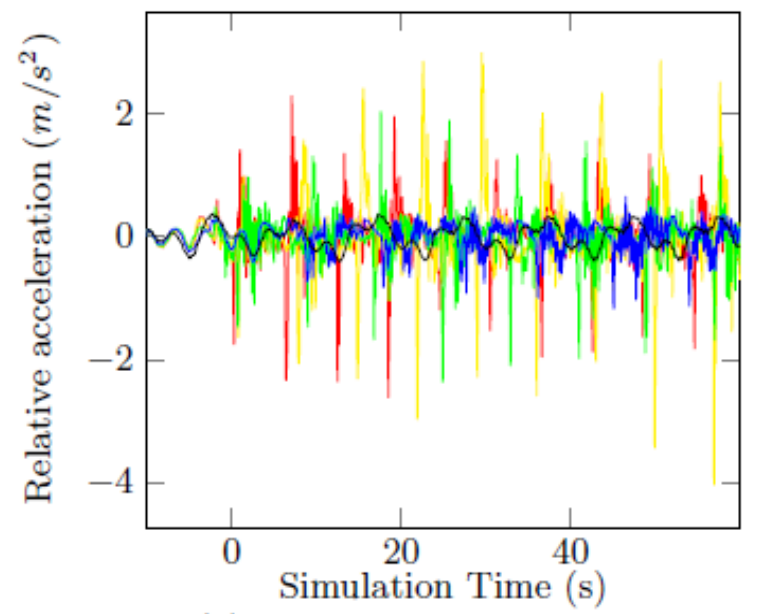

(e) Surge relative acceleration

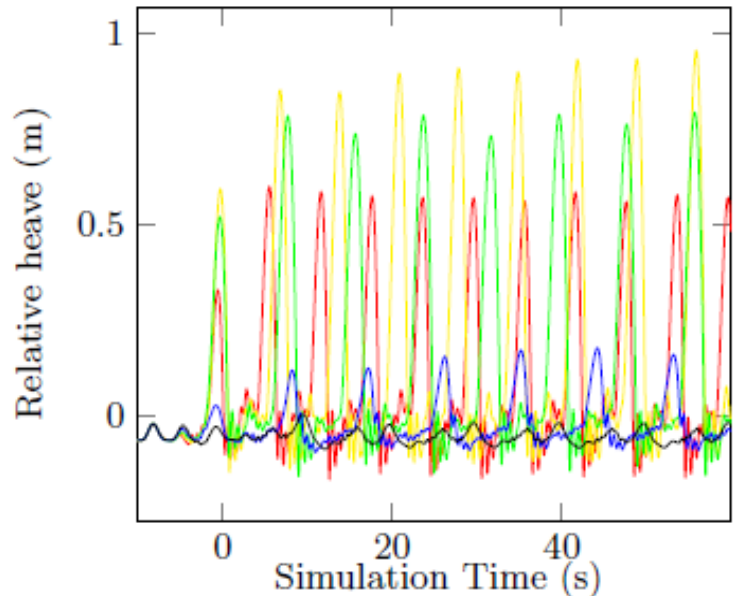

(b) Heave motion

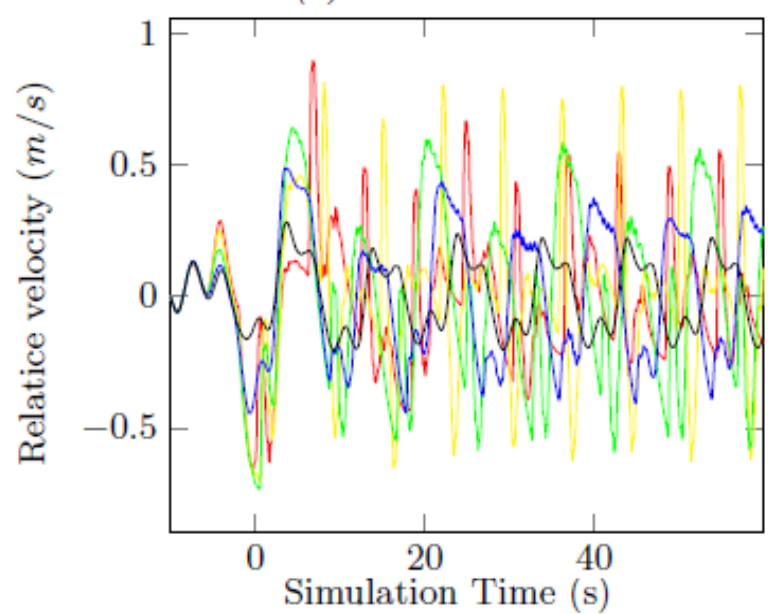

(d) Sway relative velocity

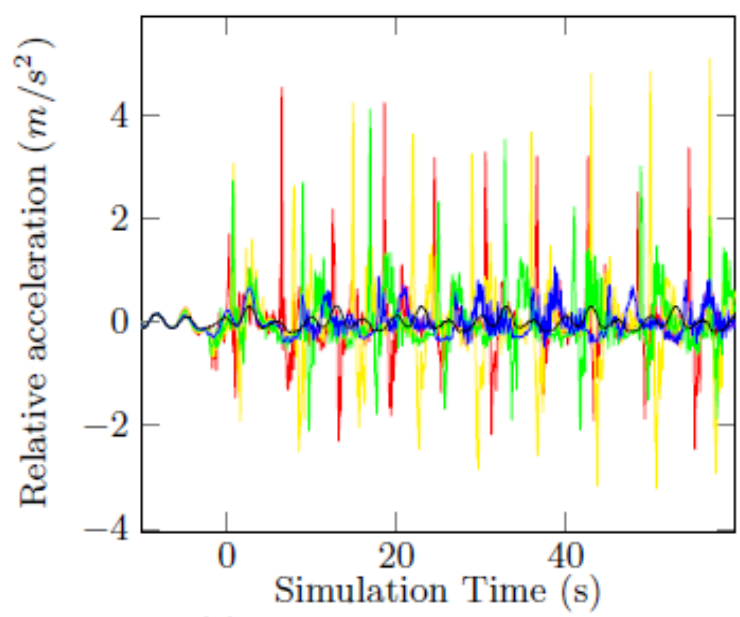

(f) Sway relative acceleration

$$
-T p=6 s-T p=7 s-T p=8 s-T p=9 s-T p=10 s
$$

Fig. 8 Base Case B: Results relative to moonpool at $H_{s}=2.5 \mathrm{~m}$ and 180 degree wave direction. 


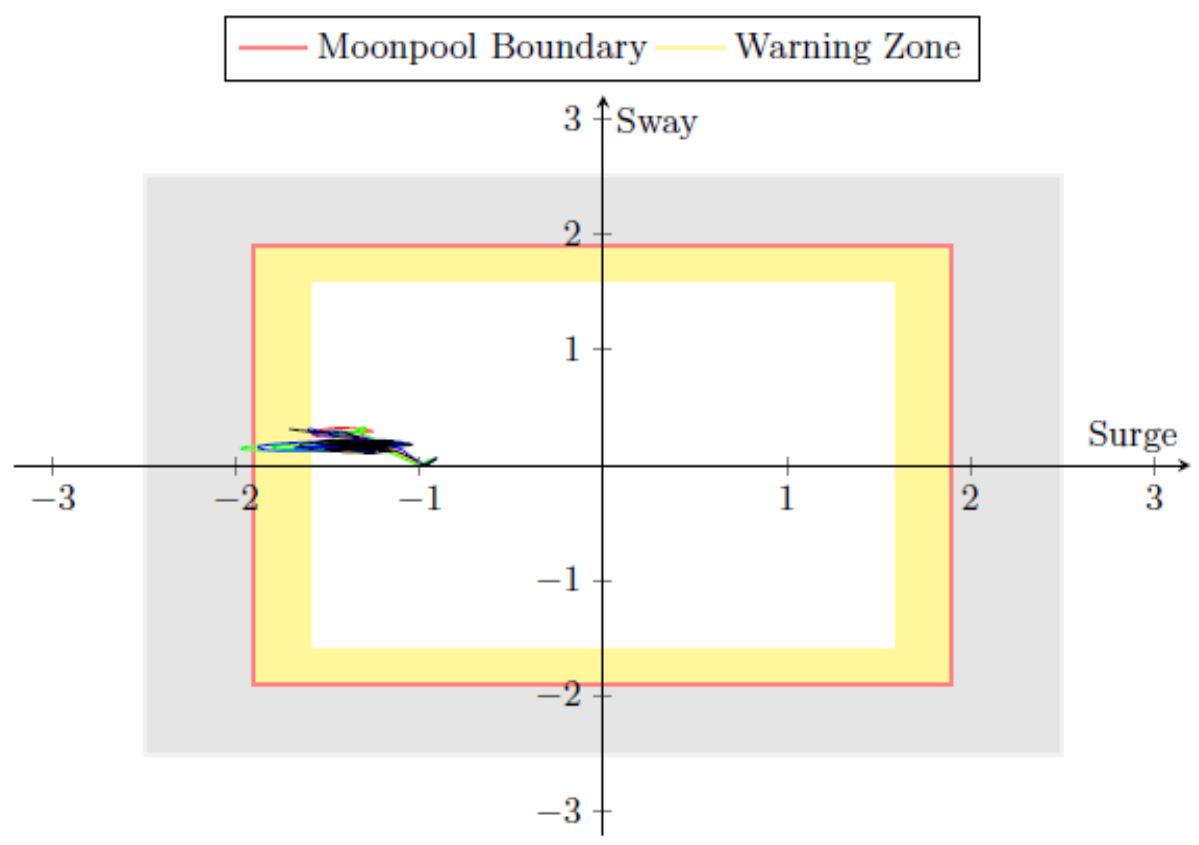

(a) Module contact clearance from moonpool bottom edges (Maximum Values) ( $m$ )

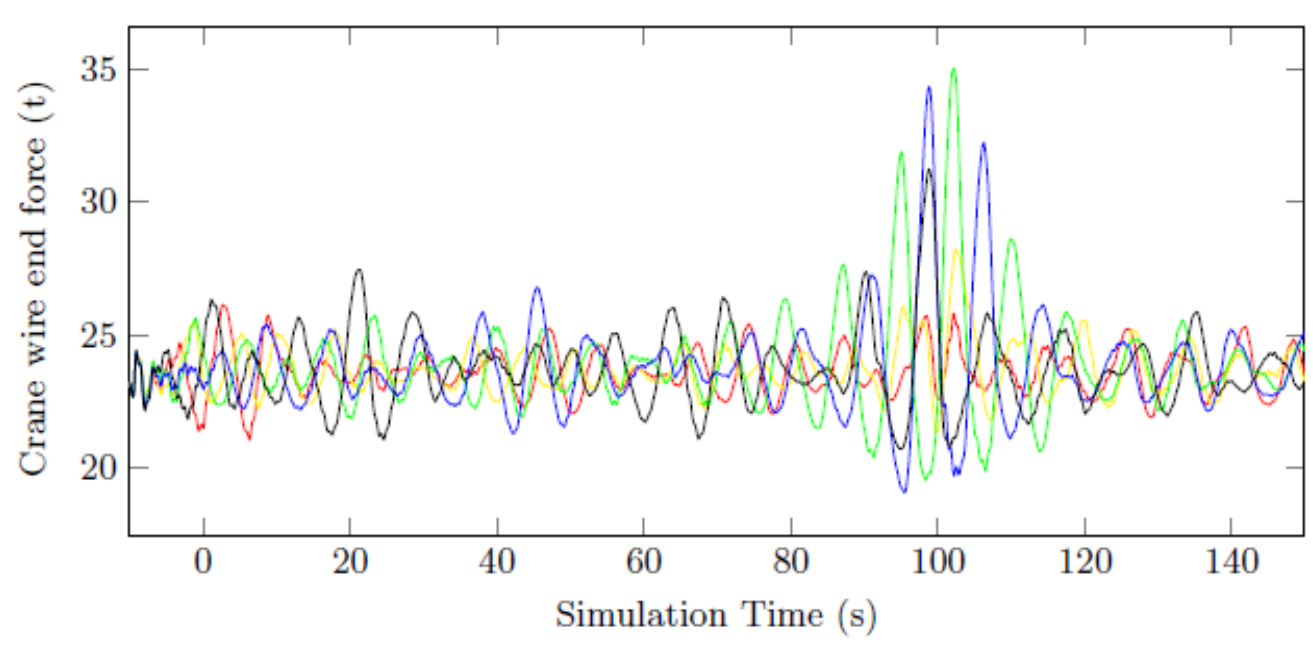

(b) Crane wire end force

$$
T p=6 s-T p=7 s-T p=8 s-T p=9 s-T p=10 s
$$

Fig. 9 Base Case C: Results relative to moonpool at $H_{s}=2.5 m$ and 180 degree wave direction.

wave height. In addition, the hydrodynamic drag coefficient of 6.5 used is the maximum drag coefficient for the module and is purposely conservative. Also, the buoyancy force contributes largely to the upward hydrodynamic load because of the geometry of the module. Therefore, snapping is expected for a wave height of as large as $5 \mathrm{~m}$, however, the values could be highly cautious.
In the point five, the motion of the module could reach up to $2 \mathrm{~m}$ high. With the assumption that the lower cursor module is only responsible for restraining lateral motions, it will be challenging for it to serve this purpose with a module vertical movement of such heights. Hence, it could be a possible constraint to the weather criteria.

In point six, the impact velocity of the object is 


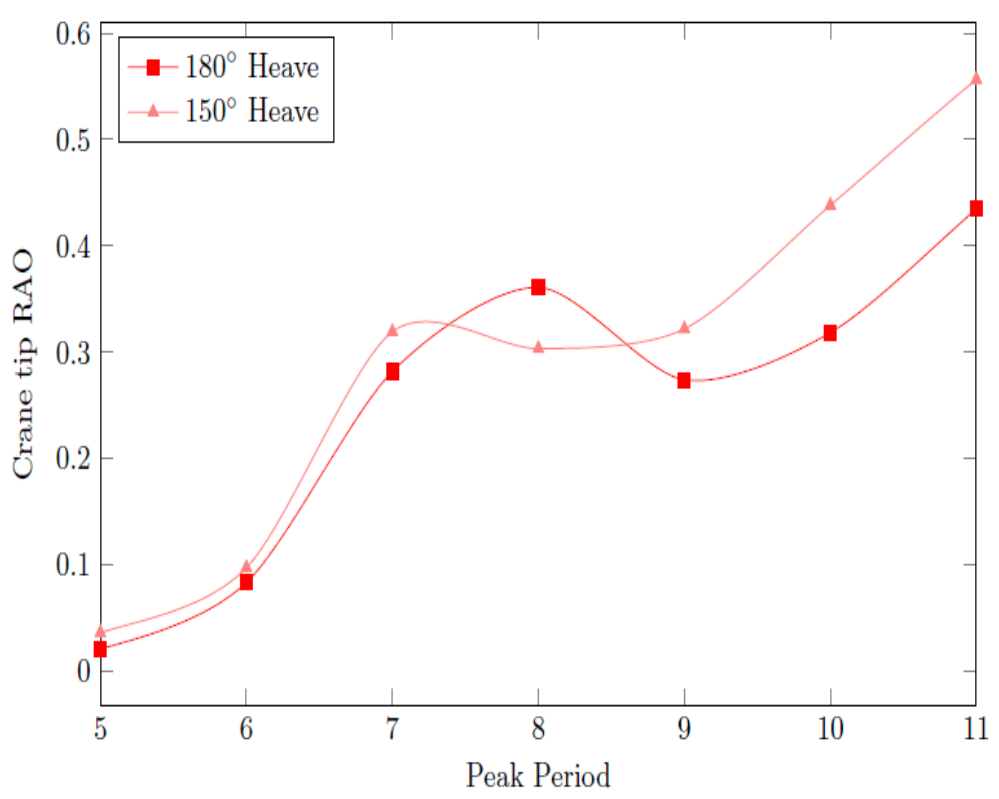

Fig. 10 Crane tip heave motion transfer functions.

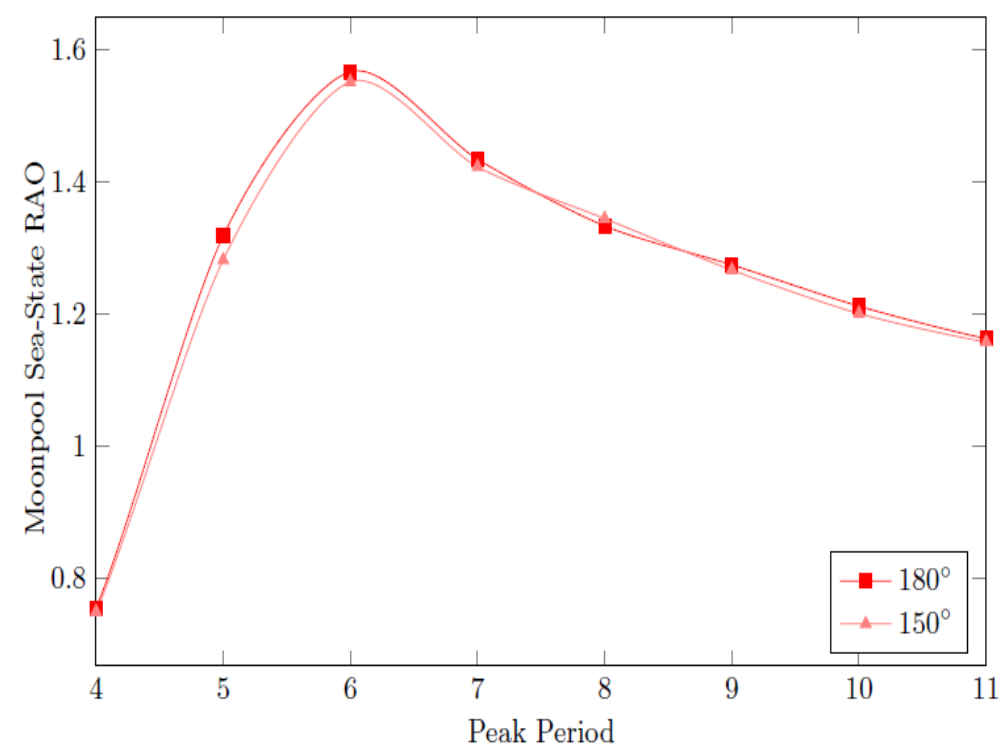

Fig. 11 Moonpool sea state RAO for different wave heading.

reaching as high as $2 \mathrm{~m} / \mathrm{s}$. The kineticenergy produced with such magnitude of velocity is equivalent to 100 $\mathrm{kJ}$. This is the value obtained if we take the static weight of the object. The buoyant weight with added mass would be slightly variant but expected to be less than the static weight. To determine the impact force would require strict understanding of the stiffness and exact configuration of the lower cursor system. This information was unavailable, but one can make a remark here that, the impact load is expected to be within limit.

A maximum $10 \mathrm{~m} / \mathrm{s}^{2}$ sway motion acceleration is mentioned in point seven. This large acceleration could result in an inertial loads of up to $50 \mathrm{t}$. The lower cursor module should be designed to handle that as well. Lastly, in point eight, the module has a high possibility of clashing. This is due to high amount of current force coupled with lateral wave forces when the module is outside the moonpool region. In addition to this, the hydrodynamic coefficients are taken as conservative 
value. However, one can observe that the module is now, away from the splash zone and vertical hydrodynamic loads are minimal, as a result the crane wire loads are immensely reduced well below the crane wire capacity.

Based on the aforementioned discussion, it is recommended to reduce the module footprint at the sea surface in order to improve the weather limit of the operation. A small footprint module has many advantages. It will have less drag area and reduce the effect of moonpool walls on drag coefficient. It will also allow more clearance between the module and the moonpool walls thus preventing the clashing between the two. However, this may mean that the module could have a larger height and larger drag area in the transverse directions.

\section{Conclusion}

An evaluation of the module deployment operation in the RLWI units was performed using the time domain analysis feature of the Orcaflex software. The results of the FMEA were used to identify the critical failure modes in the aforementioned process. The critical failure modes for our case study were, crane wire loading, impact velocity when module is inside the moonpool, and the lateral motions of the module at the keel level.

Three load cases (A, B and C) and two wave headings (180-degree and 150-degree) were used in the analysis and the results were discussed for all the three load cases. The crane wire forces were found to be larger for 180-degree wave direction. Likewise, load case A demonstrated the highest loading conditions. Furthermore, load case $\mathrm{C}$ depicted possible clashing of the module with the moonpool walls. Finally, recommendations of reducing the module footprint area on the sea surface was recommended as a possible solution for increasing up- time of the module deployment operations. Furthermore, authors propose to validate the results of the case study with the experimental results carried in the future.

\section{References}

[1] Keprate, A., and Karunakaran, D. 2014. "Appraisal of Riser Concepts for FPSO in Deepwater.” Thesis for M.Sc. in Offshore Technology, University of Stavanger, Norway.

[2] Nam, B. W., Hong, S. Y., Kim, Y. S., and Kim, J. W. 2013. "Effects of Passive and Active Heave Compensators on Deepwater Lifting Operation.” International Journal of Offshore and Polar Engineering 23 (1): 33-7.

[3] Mathiassen, E., and Skeels, H. B. 2008. "Field Experience with Riser Less Light Well Intervention.” Offshore Technology Conference, 5-8 May, Houston, Texas, USA.

[4] FMC Technologies Brochure. 2013. "Riser Less Well Intervention.”

http://www.fmctechnologies.com/SubseaSystems/Techno logies/AdvancingTechnologies/Intervention/LWI.aspx.

[5] Norsok D-002. 2013. "Well Intervention Equipment." Oslo, Norway.

[6] DNV-OS-E101. 2009. “Drilling Plant.” Oslo, Norway.

[7] Keprate, A. 2015. "Impact of Passive Heave Compensator on Offshore Lifting." Journal of Shipping and Ocean Engineering 5 (4): 166-80.

[8] Øritsland, O. 1989. “A Summary of Subsea Module Hydrodynamic Data.” Marine Operations Part III.2, MARINTEK, Norway. 


\section{Appendix}

Table A1 FMEA of the RLWI deployment operation.

\begin{tabular}{|c|c|c|c|c|c|c|c|}
\hline No. & $\begin{array}{l}\text { Equipment/ } \\
\text { procedure name }\end{array}$ & Function & Failure mode & $\begin{array}{l}\text { Failure Effect- } \\
\text { local }\end{array}$ & $\begin{array}{l}\text { Failure effect - } \\
\text { end effect }\end{array}$ & Failure detection & $\begin{array}{l}\text { Alternative provisions/ } \\
\text { redundancy/ Barriers }\end{array}$ \\
\hline 1. & $\begin{array}{l}\text { Locking of WCP } \\
\text { to RT }\end{array}$ & Lifting Support & Fracture Fatigue & $\begin{array}{l}\text { Running tool } \\
\text { disconnected }\end{array}$ & Lift off failure & $\begin{array}{l}\text { Testing of valves } \\
\text { and connection }\end{array}$ & $\begin{array}{l}\text { Several locking } \\
\text { mechanism }\end{array}$ \\
\hline 2 & $\begin{array}{l}\text { Moving WCP to } \\
\text { moonpool }\end{array}$ & $\begin{array}{l}\text { Positioning for } \\
\text { next procedure }\end{array}$ & $\begin{array}{l}\text { Getting trapped } \\
\text { or stuck }\end{array}$ & Delay & Loss of rig time & Human detection & $\begin{array}{l}\text { Lubrication/ } \\
\text { maintenance }\end{array}$ \\
\hline 3 & $\begin{array}{l}\text { Umbilical } \\
\text { Connection }\end{array}$ & $\begin{array}{l}\text { Communication } \\
\text { during Wireline } \\
\text { runs }\end{array}$ & $\begin{array}{l}\text { Electrical/ } \\
\text { hydraulic/ } \\
\text { mechanical }\end{array}$ & $\begin{array}{l}\text { Loss of } \\
\text { communication }\end{array}$ & $\begin{array}{l}\text { Operation shut } \\
\text { down }\end{array}$ & $\begin{array}{l}\text { Work over control } \\
\text { system (WOCS) }\end{array}$ & $\begin{array}{l}\text { Proper design and } \\
\text { analysis of the } \\
\text { Umbilical Termination } \\
\text { Head }\end{array}$ \\
\hline 4 & Guide Wires & $\begin{array}{l}\text { Guide the stack } \\
\text { from lateral } \\
\text { motions }\end{array}$ & $\begin{array}{l}\text { Plastic } \\
\text { deformation/ } \\
\text { rupture }\end{array}$ & $\begin{array}{l}\text { Loss of } \\
\text { hydrodynamic } \\
\text { stability }\end{array}$ & $\begin{array}{l}\text { Clashing or drift } \\
\text { off }\end{array}$ & $\begin{array}{l}\text { Analysis of } \\
\text { maximum } \\
\text { expected } \\
\text { hydrodynamic } \\
\text { load }\end{array}$ & $\begin{array}{l}\text { High tension capacity } \\
\text { wires or Reduce weight } \\
\text { of equipment }\end{array}$ \\
\hline 5 & Landing of WCP & To lock the WCP & $\begin{array}{l}\text { High landing } \\
\text { speed }\end{array}$ & $\begin{array}{l}\text { Impact force on } \\
\text { WCP and XT }\end{array}$ & $\begin{array}{l}\text { Damage the } \\
\text { Equipment }\end{array}$ & $\begin{array}{l}\text { Analysis of } \\
\text { Maximum possible } \\
\text { heave speed }\end{array}$ & $\begin{array}{l}\text { Use active heave } \\
\text { compensator to reduce } \\
\text { the heave velocity }\end{array}$ \\
\hline 6 & WROV & $\begin{array}{l}\text { Disconnect } \\
\text { Running tools }\end{array}$ & $\begin{array}{l}\text { Mechanical/ } \\
\text { electrical failure }\end{array}$ & $\begin{array}{l}\text { unable to remove } \\
\text { running tool }\end{array}$ & $\begin{array}{l}\text { Operation halted } \\
\text { until ROV fixed }\end{array}$ & $\begin{array}{l}\text { ROV panel } \\
\text { control system }\end{array}$ & $\begin{array}{l}\text { Use additional WROV } \\
\text { and continuous } \\
\text { maintenance to reduce } \\
\text { risk }\end{array}$ \\
\hline 7 & $\begin{array}{l}\text { WCP to LS } \\
\text { connection }\end{array}$ & $\begin{array}{l}\text { Seal the } \\
\text { connection }\end{array}$ & $\begin{array}{l}\text { Incorrect landing } \\
\text { angle, fatigue }\end{array}$ & $\begin{array}{l}\text { Drifting/ or } \\
\text { buckling }\end{array}$ & $\begin{array}{l}\text { Stack badly } \\
\text { damaged, Risk of } \\
\text { blowout }\end{array}$ & $\begin{array}{l}\text { Testing on deck } \\
\text { and WROV } \\
\text { inspection }\end{array}$ & $\begin{array}{l}\text { Follow procedures, } \\
\text { and post machining of } \\
\text { welds }\end{array}$ \\
\hline 8 & $\begin{array}{l}\text { Wireline Tool } \\
\text { string }\end{array}$ & $\begin{array}{l}\text { Wire to connect } \\
\text { wireline tool to } \\
\text { topside facilities }\end{array}$ & $\begin{array}{l}\text { Plastic } \\
\text { deformation/ } \\
\text { rupture }\end{array}$ & $\begin{array}{l}\text { Loss of wireline } \\
\text { tool }\end{array}$ & $\begin{array}{l}\text { Operation halt, } \\
\text { complication on } \\
\text { well management }\end{array}$ & $\begin{array}{l}\text { Temperature and } \\
\text { H2S detection } \\
\text { from fiber optics }\end{array}$ & $\begin{array}{l}\text { Appropriate quality } \\
\text { wireline }\end{array}$ \\
\hline 9 & Wire rope & $\begin{array}{l}\text { Vertical hoisting } \\
\text { support }\end{array}$ & $\begin{array}{l}\text { Snatching due to } \\
\text { snap load }\end{array}$ & $\begin{array}{l}\text { Equipment } \\
\text { sinking }\end{array}$ & $\begin{array}{l}\text { Damage to XT, } \\
\text { Stack and chance } \\
\text { of loss of stability }\end{array}$ & $\begin{array}{l}\text { Analysis of snap/ } \\
\text { hydrodynamic } \\
\text { loads }\end{array}$ & $\begin{array}{l}\text { High quality crane } \\
\text { wire }\end{array}$ \\
\hline
\end{tabular}

